\title{
Research and Technological Development on Bio-Energy
}

\author{
Abdeen Mustafa Omer \\ Energy Research Institute Nottingham NG7 4EU, United Kingdom
}

\begin{abstract}
This paper discusses a comprehensive review of biomass energy sources, environment and sustainable development. This includes the biomass energy technologies, energy efficiency systems, energy conservation scenarios, energy savings and other measures necessary to reduce climate change. Energy use reductions can be achieved by minimising the energy demand, by rational energy use, and by recovering heat. The increased availability of reliable and efficient energy services stimulates the use of more green energies. The adoption of green or sustainable approaches to the way in which society is run is seen as an important strategy in finding a solution to the energy problem. The key factors to reducing and controlling $\mathrm{CO}_{2}$ emissions to the atmospheric sink, which is the major contributor to global warming, are the use of alternative approaches to energy generation and the exploration of how these alternatives are used today and may be used in the future as green energy sources.
\end{abstract}

Keywords Biomass, Wastes, Bi-Wastes, Bioenergy, Biogas

\section{Introduction}

Energy is an essential factor in development since it stimulates, and supports economic growth and development. Fossil fuels, especially oil and natural gas, are finite in extent, and should be regarded as depleting assets, and efforts are oriented to search for new sources of energy. The clamour all over the world for the need to conserve energy and the environment has intensified as traditional energy resources continue to dwindle whilst the environment becomes increasingly degraded. Alternative energy sources can potentially help fulfill the acute energy demand and sustain economic growth in many regions of the world[1-4]. Energy security, economic growth and environment protection are the national energy policy drivers of any country of the world. As world populations grow, many faster than the average $2 \%$, the need for more and more energy is exacerbated[5]. Enhanced lifestyle and energy demand rise together and the wealthy industrialised economics, which contain $25 \%$ of the world's population, consume $75 \%$ of the world's energy supply[6-8]. The world's energy consumption today is estimated to 22 billion $\mathrm{kWh}$ per year[8-10]. About 6.6 billion metric tons carbon equivalent of greenhouse gas (GHG) emission are released in the atmosphere to meet this energy demand[11-14]. Approximately $80 \%$ is due to carbon emissions from the combustion of energy fuels[14-16]. At the current rate of usage, taking into consideration population increases and higher consumption of energy by developing countries, oil resources, natural gas and uranium will be

* Corresponding author:

abdeenomer2@yahoo.co.uk (Abdeen Mustafa Omer)

Published online at http://journal.sapub.org/ijee

Copyright (C) 2012 Scientific \& Academic Publishing. All Rights Reserved depleted within a few decades. Bioenergy is beginning to gain importance in the global fight to prevent climate change [17-20]. The scope for exploiting organic waste as a source of energy is not limited to direct incineration or burning refuse-derived fuels. Biogas, biofuels and woody biomass are other forms of energy sources that can be derived from organic waste materials. These biomass energy sources have significant potential in the fight against climate change. Technological progress has dramatically changed the world in a variety of ways. It has, however, also led to developments, e.g., environmental problems, which threaten man and nature. Build-up of carbon dioxide and other GHGs is leading to global warming with unpredictable but potentially catastrophic consequences. When fossil fuels burn, they emit toxic pollutants that damage the environment and people's health with over 700,000 deaths resulting each year, according to the World Bank review of 2000[21-28].

The sources to alleviate the energy situation in the world are sufficient to supply all foreseeable needs[29-34]. Conservation of energy and rationing in some form will however have to be practised by most countries, to reduce oil imports and redress balance of payments positions. Meanwhile development and application of nuclear power and some of the traditional solar, wind, biomass and water energy alternatives must be set in hand to supplement what remains of the fossil fuels.

The encouragement of greater energy use is an essential component of development. In the short-term, it requires mechanisms to enable the rapid increase in energy/capita, and in the long-term we should be working towards a way of life, which makes use of energy efficiency and clean environment without causing safety problems[35-37]. Such a programme should as far as possible be based on renewable energy resources. 
Large-scale, conventional, power plant such as hydropower has an important part to play in development. It does not, however, provide a complete solution. There is an important complementary role for the greater use of small-scale, rural based-power plants. Such plant can be used to assist development since it can be made locally using local resources, enabling a rapid built-up in total equipment to be made without a corresponding and unacceptably large demand on central funds. Renewable resources are particularly suitable for providing the energy for such equipment and its use is also compatible with the long-term aims. In compiling energy consumption data one can categorise usage according to a number of different schemes:

- Traditional sector- industrial, transportation, etc.

- End-use- space heating, process steam, etc.

- Final demand- total energy consumption related to automobiles, to food, etc.

- Energy source- oil, coal, etc.

- Energy form at point of use- electric drive, low temperature heat, etc.

The scope for exploiting organic waste as a source of energy is not limited to direct incineration or burning refuse-derived fuels. Biogas, biofuels and woody biomass are other forms of energy sources that can be derived from organic waste materials. These biomass energy sources have significant potential in the fight against climate change. Energy is a vital prime mover to the development whether in urban or rural areas. The rural energy needs are modest compared to urban. A shift to renewable technologies would therefore help solve some of these problems while also providing the population with higher quality energy, which will in turn, improve living standards and help reduce poverty. For proper rural development the following must be considered:

- Analyse the key potentials and constraints of development of rural energy.

- Assess the socio-technical information needs for decision-makers and planners in rural development.

- Utilise number of techniques and models supporting planning rural energy.

- Design, import and interpret different types of surveys to collect relevant information and analyse them to be an input to planners.

\section{Biomass Potential}

This section discusses a comprehensive review of biomass energy sources, environment and sustainable development. This includes all the biomass energy technologies, energy efficiency systems, energy conservation scenarios, energy savings and other mitigation measures necessary to reduce emissions.

\subsection{Bio-Wastes Development}

Waste is defined as an unwanted material that is being discarded. Waste includes items being taken for further use, recycling or reclamation. Waste produced at household, commercial and industrial premises are control waste and come under the waste regulations. Waste Incineration Directive (WID) emissions limit values will favour efficient, inherently cleaner technologies that do not rely heavily on abatement[38-39]. For existing plants, the requirements are likely to lead to improved control of:

- $\mathrm{NO}_{\mathrm{x}}$ emissions, by the adoption of furnace combustion control and abatement techniques.

- Acid gases, by the adoption of abatement techniques and optimisation of their control.

- Particulate control techniques, and their optimisation, e.g., of bag filters and electrostatic precipitators.

Bioenergy ${ }^{1}$ is energy from the sun stored in materials of biological origin[40-42]. This includes plant matter and animal waste, known as biomass. Plants store solar energy through photosynthesis in cellulose and lignin, whereas animals store energy as fats. When burned, these sugars break down and release energy exothermically, releasing carbon dioxide, heat and steam. The by-products of this reaction can be captured and manipulated to create power, commonly called bioenergy ${ }^{1}[43-45]$. Biomass is considered renewable because the carbon is taken out of the atmosphere and replenished more quickly than the millions of years required for fossil fuels to form. The use of biofuels to replace fossil fuels contributes to a reduction in the overall release of carbon dioxide into the atmosphere and hence helps to tackle global warming[46-52]. The use of sustainably produced biofuels contributes no net atmospheric $\mathrm{CO}_{2}$. Sustainable production assumes that the rate of biofuel utilisation equals the rate of biofuel synthesis, provided that the process does not require a net input of fossil fuels. For example, corn-based ethanol does not fit the description of sustainably produced biofuels in that the corn production requires large amounts of petrochemicals in the form of pesticides and fertilisers. The range of waste treatment technologies that are tailored to produce bioenergy is growing. There are a number of key areas of bioenergy from wastes including (but not limited to) biogas, biofuels and bioheat. When considering using bioenergy, it is important to take into account the overall emission of carbon in the process of electricity production. The biomass energy resources are particularly suited for the provision of rural power supplies and a major advantage is that equipment such as flat plate solar driers, wind turbines, etc., can be constructed using local resources and without the high capital cost of more conventional equipment. Further advantage results from the feasibility of local maintenance and the general encouragement such local manufacture gives to the build up of small-scale rural based industry. Table 1 lists the energy sources available for poor people in developing countries.

Currently the 'non-commercial' fuels wood, crop residues and animal dung are used in large amounts in the rural areas of developing countries, principally for heating and cooking; the method of use is highly inefficient[57-59]. Table 2 presented some renewable applications. Table 3 lists the most 
important of energy needs[63] for household. Table 4 Methods of energy conversion. Considerations when selecting power plants include the following:

- Power level- whether continuous or discontinuous.

- Cost- initial cost, total running cost including fuel, maintenance and capital amortised over life.

- Complexity of operation, and suitability for local manufacture.

- Maintenance and availability of spares, and life.

- Management and modifications of environments in use.

Table 1. Sources of energy for people in developing countries[53-56]

\begin{tabular}{|c|c|c|}
\hline $\begin{array}{c}\text { Energy } \\
\text { source }\end{array}$ & $\begin{array}{c}\text { Energy } \\
\text { carrier }\end{array}$ & Energy end-use \\
\hline Vegetation & Fuel-wood & $\begin{array}{c}\text { Cooking } \\
\text { Water heating } \\
\text { Building materials } \\
\text { Animal fodder preparation }\end{array}$ \\
\hline Oil & Kerosene & $\begin{array}{c}\text { Lighting } \\
\text { Ignition fires }\end{array}$ \\
\hline Dry cells & $\begin{array}{c}\text { Dry cell } \\
\text { batteries }\end{array}$ & $\begin{array}{c}\text { Lighting } \\
\text { Small appliances }\end{array}$ \\
\hline $\begin{array}{c}\text { Muscle } \\
\text { power }\end{array}$ & $\begin{array}{c}\text { Animal } \\
\text { power }\end{array}$ & $\begin{array}{c}\text { Transport } \\
\text { Fond preparation for farming }\end{array}$ \\
\hline $\begin{array}{c}\text { Muscle } \\
\text { power }\end{array}$ & $\begin{array}{c}\text { Human } \\
\text { power }\end{array}$ & $\begin{array}{c}\text { Transport } \\
\text { Land preparation for farming } \\
\text { Food preparation (threshing) }\end{array}$ \\
\hline
\end{tabular}

Table 2. Energy applications[60-62]

\begin{tabular}{|l|l|}
\hline \multicolumn{1}{|c|}{ Systems } & \multicolumn{1}{c|}{ Applications } \\
\hline Water supply & $\begin{array}{l}\text { Rain collection, purification, storage and } \\
\text { recycling }\end{array}$ \\
\hline Wastes disposal & Anaerobic digestion $\left(\mathrm{CH}_{4}\right)$ \\
\hline Cooking & Methane \\
\hline Food & $\begin{array}{l}\text { Cultivate the 1 hectare plot and green- } \\
\text { house for four people }\end{array}$ \\
\hline Electrical demands & Wind generator \\
\hline Space heating & Solar collectors \\
\hline Water heating & Solar collectors and excess wind energy \\
\hline Control system & Ultimately hardware \\
\hline Building fabric & Integration of subsystems to cut costs \\
\hline
\end{tabular}

Table 3. Energy needs in rural areas[63]

\begin{tabular}{|l|}
\hline Transport, e.g., small vehicles and boats \\
\hline Agricultural machinery, e.g., two-wheeled tractors \\
\hline Crop processing, e.g., milling \\
\hline Water pumping \\
\hline Small industries, e.g., workshop equipment \\
\hline Electricity generation, e.g., hospitals and schools \\
\hline Domestic, e.g., cooking, heating, and lighting \\
\hline
\end{tabular}

Table 4. Methods of energy conversion[64]

\begin{tabular}{|l|l|}
\hline Muscle power & Man, animals \\
\hline Internal combustion engines & Petrol- spark ignition \\
\hline Reciprocating & Diesel- compression ignition \\
\hline Rotating & Humphrey water piston \\
\hline Heat engines & Gas turbines \\
\hline Vapour (Rankine) & \\
\hline Reciprocating & Steam engine \\
\hline Rotating & Steam turbine \\
\hline Gas Stirling (Reciprocating) & Steam engine \\
\hline Gas Brayton (Rotating) & Steam turbine \\
\hline Electron gas & Thermionic, and thermoelectric \\
\hline Electromagnetic radiation & Photo devices \\
\hline Hydraulic engines & Wheels, screws, buckets, and turbines \\
\hline Wind engines (wind machines) & Vertical axis, and horizontal axis \\
\hline Electrical/mechanical & Dynamo/alternator, and motor \\
\hline
\end{tabular}

The internal combustion engine, currently running exclu- sively on fossil gasoline, is a major contributor to rising $\mathrm{CO}_{2}$ emissions worldwide and some pretty dramatic new thinking is needed if our planet is to counter the effects. While its use is increasing in developing world economies, automotive research should be geared towards low-emissions technologies in order to keep inner-city environments free from waste, litter and grime. Materials handled by waste management companies are becoming increasingly valuable. Those responsible for the security of facilities that treat waste or manage scrap will testify to the precautions needed to fight an ongoing battle against unauthorised access by criminals and crucially, to prevent the damage they can cause through theft, vandalism or even arson. Of particular concern is the escalation of metal theft, driven by various factors including the demand for metal in rapidly developing economies such as India and China. Table 4 listed methods of energy conversion.

The environment sustains the essence and quality of human life in all its aspects, and is therefore priceless. Therefore, human energy use and activity should fully integrate itself in the biosphere, akin to plants, algae, bacteria, fungi, animals and insects (Figure 1). Obviously, man uses energy just as plants, bactria, mishrooms, bees, fish and rats do. That is, all metabolic "waste" products are also substrates within the biosphere. Against this paradigm, the petrochemical and nuclear industries produces xenobiotics, which cannot be degraded nor utilised within the biosphere and are often highly toxic.

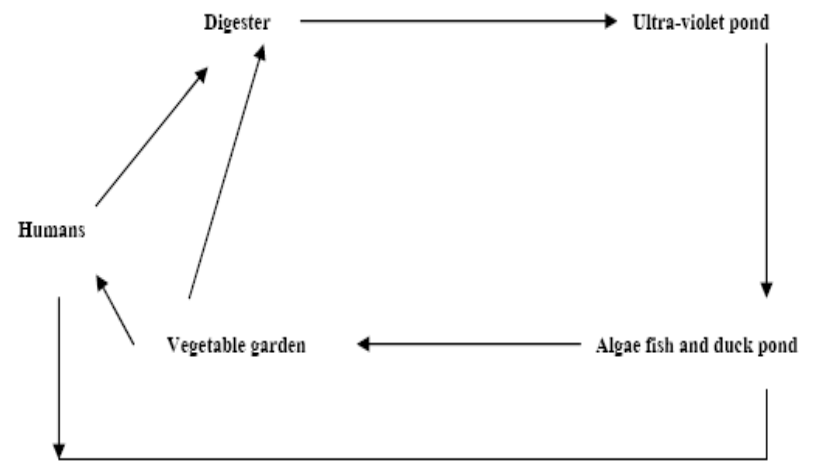

Figure 1. Biomass utilisation concept

The economic values tied to the environment are increasingly recognised. Hence, new approaches such as Life Cycle Analysis aim to promote sustainable process design. However, implementations still face issue is market uncertainties weak appropriability regime, and difficulties in reconfiguring organisational routines.

There is a need for greater attention towards the development of new designs, the dissemination of information and the encouragement of its use. International and government bodies as well as independent organisations all have a role to play in promoting biomass energy technologies.

The degradation of the global environment is one of the most serious issues stemming from energy production. Various alternatives are considered for effective mitigation of climate change, acid rain or other environmental pollutions. 


\subsection{Energy use and the Environment}

Energy use is one of several essential components for both developed and developing countries uses energy though in varying ratio:

- The overall situation and the implications of increased energy use in the future.

- The problem of power supply in rural areas, including the consideration of energy resources and energy conversion.

Compared to the current, and often excessive, energy use per capita in developed countries, developing countries can move towards alternatives, which, whilst maintaining or even increasing quality of life, reduce significantly the energy consumption per capita. Such savings can be achieved in a number of ways:

- Improved efficiency of energy use, for example better thermal insulation, and energy recovery.

- Improved designs reflecting energy conservation, long product life through reuse and post-consumer recycling strategies.

For example in the field of transport, the aim of any modern biomass energy systems must be:

- To maximise yields with minimum inputs.

- Utilisation and selection of adequate plant materials and processes.

- Optimum use of land, water and organic fertiliser.

- Create an adequate infrastructure for strong R \& D base.

Furthermore, investigating is needed the potential for better waste valorisation. Household waste, vegetable market waste, and waste from the cotton stalks, leather, and pulp; and paper industries can be used to produce useful energy either by direct incineration, gasification, digestion (biogas production), fermentation, or cogeneration. Therefore, effort has to be made to reduce fossil energy use and to promote green energies, particularly in the building sector. Energy use reductions can be achieved by minimising the energy demand, by rational energy use, by recovering heat and the use of more green energies. Energy ratio is defined as the ratio of energy content of the food product/energy input to produce the food.

$$
\mathrm{Er}=\mathrm{Ec} / \mathrm{Ei}
$$

Where: Er is the energy ratio, Ec is the energy contents of the food product, and $\mathrm{Ec}$ is the Energy input to produce the food.

\subsection{Combined Heat and Power (CHP)}

The atmospheric emissions of fossil fuel installations are mostly aldehydes, carbon monoxide, nitrogen oxides, sulphur oxides and particles (i.e., ash) as well as carbon dioxide. Table 5 shows estimates include not only the releases occurring at the power plant itself but also cover fuel extraction and treatment, as well as the storage of wastes and the area of land required for operation (Table 6). A review of the potential range of recyclables is presented in Table 7.

Combined heat and power (CHP) installations are quite common in greenhouses, which grow high-energy, input crops (e.g., salad vegetables, pot plants, etc.). Scientific assumptions for a short-term energy strategy suggest that the most economically efficient way to replace the thermal plants is to modernise existing power plants to increase their energy efficiency and to improve their environmental performance. However, utilisation of wind power and the conversion of gas-fired CHP plants to biomass would significantly reduce the dependence on imported fossil fuels. Although a lack of generating capacity is forecasted in the long-term, utilisation of the existing renewable energy potential and the broad possibilities for increasing energy efficiency are sufficient to meet future energy demands in the short-term.

Table 5. Annual GHG emissions from different sources of power plants [65]

\begin{tabular}{|c|c|c|c|c|}
\hline \multirow{2}{*}{$\begin{array}{c}\text { Primary source of } \\
\text { energy }\end{array}$} & \multicolumn{2}{|c|}{ Emissions (x 10 metric tons) } & Waste (x 10 metric tons) & Area $\left(\mathrm{km}^{2}\right)$ \\
\cline { 2 - 5 } & Atmosphere & Water & & \\
\hline Coal & 380 & $7-41$ & $60-3000$ & 120 \\
\hline Oil & $70-160$ & $3-6$ & Negligible & $70-84$ \\
\hline Gas & 24 & 1 & - & 84 \\
\hline Nuclear & 6 & 21 & 2600 & 77 \\
\hline
\end{tabular}

Table 6. Energy consumption per population [66]

\begin{tabular}{|c|c|c|}
\hline Region & Population (millions) & Energy $\left(\right.$ Watt $\left./ \mathrm{m}^{2}\right)$ \\
\hline Africa & 820 & 0.54 \\
\hline Asia & 3780 & 2.74 \\
\hline Central America & 180 & 1.44 \\
\hline North America & 335 & 0.34 \\
\hline South America & 475 & 0.52 \\
\hline Western Europe & 445 & 2.24 \\
\hline Eastern Europe & 130 & 2.57 \\
\hline Oceania & 35 & 0.08 \\
\hline Russia & 330 & 0.29 \\
\hline
\end{tabular}


Table 7. Summary of material recycling practices in the construction sector[67]

\begin{tabular}{|c|c|c|}
\hline $\begin{array}{c}\text { Construction and } \\
\text { demolition material }\end{array}$ & Recycling technology options & Recycling product \\
\hline Asphalt & $\begin{array}{l}\text { Cold recycling: heat generation; Minnesota process; } \\
\text { parallel drum process; elongated drum; microwave } \\
\text { asphalt recycling system; surface regeneration }\end{array}$ & Recycling asphalt; asphalt aggregate \\
\hline Brick & Burn to ash, crush into aggregate & Slime burn ash; filling material; hardcore \\
\hline Concrete & Crush into aggregate & $\begin{array}{l}\text { Recycling aggregate; cement replacement; protection of } \\
\text { levee; backfilling; filter }\end{array}$ \\
\hline Ferrous metal & Melt; reuse directly & Recycled steel scrap \\
\hline Glass & $\begin{array}{l}\text { Reuse directly; grind to powder; polishing; crush into } \\
\text { aggregate; burn to ash }\end{array}$ & $\begin{array}{l}\text { Recycled window unit; glass fibre; filling material; tile; } \\
\text { paving block; asphalt; recycled aggregate; cement replace- } \\
\text { ment; manmade soil }\end{array}$ \\
\hline Masonry & Crush into aggregate; heat to $900^{\circ} \mathrm{C}$ to ash & Thermal insulating concrete; traditional clay \\
\hline Non-ferrous metal & Melt & Recycled metal \\
\hline Paper and cardboard & Purification & Recycled paper \\
\hline Plastic & $\begin{array}{l}\text { Convert to powder by cryogenic milling; clopping; crush } \\
\text { into aggregate; burn to ash }\end{array}$ & $\begin{array}{l}\text { Panel; recycled plastic; plastic lumber; recycled aggregate; } \\
\text { landfill drainage; asphalt; manmade soil }\end{array}$ \\
\hline Timber & $\begin{array}{l}\text { Reuse directly; cut into aggregate; blast furnace deoxi- } \\
\text { disation; gasification or pyrolysis; chipping; moulding } \\
\text { by pressurising timber chip under steam and water }\end{array}$ & $\begin{array}{l}\text { Whole timber; furniture and kitchen utensils; lightweight } \\
\text { recycled aggregate; source of energy; chemical production; } \\
\text { wood-based panel; plastic lumber; geofibre; insulation board }\end{array}$ \\
\hline
\end{tabular}

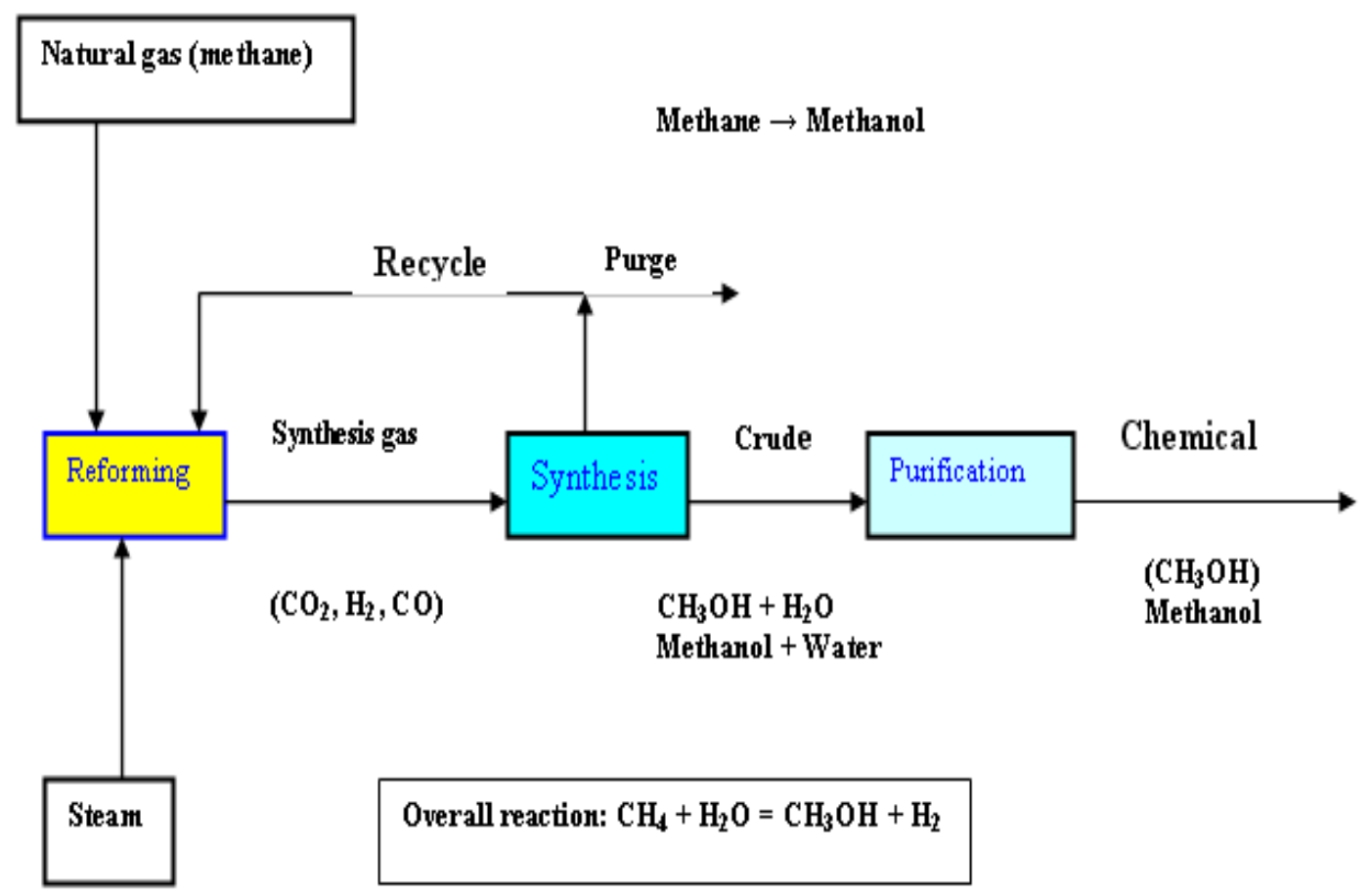

Figure 2. Schematic process flowsheet

A total shift towards a sustainable energy system is a complex and long process, but is one that can be achieved within a period of about 20 years. Implementation will require initial investments, long-term national strategies and action plans. However, Figure 2 shows the changes will have a number of benefits including a more stable energy supply than at present and major improvement in the environmental performance of the energy sector, and definite social benefits.

Computer modelling was used to assess various scenarios. The methodology utilised:

- Data from existing governmental programmes.

- Potential renewable energy sources and energy efficiency improvements.
- Assumptions for future economy growth.

- Information from studies and surveys on the recent situation in the energy sector.

- Environmental design and engineering.

The main advantages projected both at the national level and international levels can be summarised as follows:

- Reduction of dependence on import of energy and related products.

- Reduction of environmental impact of energy production (greenhouse effect, air pollution, and ecosystem degradation).

- Substitution of food crops and reduction of food surpluses and of related economic burdens.

- Utilisation of marginal lands and of set aside lands and 
reduction of related socio-economic and environmental problems (soil erosion, urbanisation, landscape deterioration, etc.).

- Development of new know-how and production of technological innovations.

In some countries, a wide range of economic incentives and other measures are already helping to protect the environment. These include:

- Taxes and user charges that reflect the costs of using the environment, e.g., pollution taxes and waste disposal charges.

- Subsidies, credits and grants that encourage environmental protection.

- Deposit-refund systems that prevent pollution on resource misuse and promote product reuse or recycling.

- Financial enforcement incentives, e.g., fines for non -compliance with environmental regulations.

- Tradable permits for activities that harm the environment.

District Heating (DH), also known as community heating can be a key factor to achieve energy savings, reduce $\mathrm{CO}_{2}$ emissions and at the same time provide consumers with a high quality heat supply at a competitive price. DH should generally only be considered for areas where the heat density is sufficiently high to make DH economical. In countries like Denmark DH may today be economical even to new developments with lower density areas due to the high level of taxation on oil and gas fuels combined with the efficient production of DH [68].

To improve the opportunity for DH local councils can adapt the following plan:

- Analyse the options for heat supply during local planning stage.

- In areas where DH is the least cost solution it should be made part of the infrastructure just like for instance water and sewage connecting all existing and new buildings.

- Where possible all public buildings should be connected to DH.

- The government provides low interest loans or funding to minimise conversion costs for its citizens.

- Use other powers, for instance national legislation to ensure the most economical development of the heat supply and enable an obligation to connect buildings to a $\mathrm{DH}$ scheme.

Denmark has broadly seen three scales of CHP which where largely implemented in the following chronological order [69]:

- Large-scale CHP in cities (>50 MW electrical power).

- Small (5 kW electrical power - $5 \mathrm{MW}$ electrical power) and medium-scale (5-50 MW electrical power).

- Industrial and small-scale CHP.

Most of the heat is produced by large CHP plants (gas-fired combined cycle plants using natural gas, biomass, waste or biogas). DH is energy efficient because of the way the heat is produced and the required temperature level is an important factor. Buildings can be heated to temperature of $21^{\circ} \mathrm{C}$ and domestic hot water (DHW) can be supplied with a temperature of $55^{\circ} \mathrm{C}$ using energy sources that are most efficient when producing low temperature levels $\left(<95^{\circ} \mathrm{C}\right)$ for the $\mathrm{DH}$ water. Most of these heat sources are $\mathrm{CO}_{2}$ neutral or emit low levels. Only a few of these sources are available to small individual systems at a reasonably cost, whereas DH schemes because of the plant's size and location can have access to most of the heat sources and at a low cost. Low temperature $\mathrm{DH}$, with return temperatures of around $30-40^{\circ} \mathrm{C}$ can utilise the following heat sources:

- Efficient use of CHP by extracting heat at low calorific value (CV).

- Efficient use of biomass or gas boilers by condensing heat in economisers (Table 8), and efficient utilisation of geothermal energy.

- Direct utilisation of excess low temperature heat from industrial processes.

- Efficient use of large-scale solar heating plants.

Table 8. Final energy projections including biomass (Mtoe, Million tone of oil equivalent)[70]

\begin{tabular}{|c|c|c|c|c|}
\hline \multicolumn{5}{|c|}{ Region 1995} \\
\hline & Biomass & $\begin{array}{c}\text { Conventional } \\
\text { Energy }\end{array}$ & Total & $\begin{array}{c}\text { Share of } \\
\text { Biomass (\%) }\end{array}$ \\
\hline Africa & 205 & 136 & 341 & 60 \\
\hline China & 206 & 649 & 855 & 24 \\
\hline East Asia & 106 & 316 & 422 & 25 \\
\hline Latin America & 73 & 342 & 415 & 18 \\
\hline South Asia & 235 & 188 & 423 & 56 \\
\hline $\begin{array}{c}\text { Total developing } \\
\text { countries }\end{array}$ & 825 & 1632 & 2457 & 34 \\
\hline $\begin{array}{c}\text { Other non-OECD* } \\
\text { countries }\end{array}$ & 24 & 1037 & 1061 & 2 \\
\hline $\begin{array}{c}\text { Total non-OECD* } \\
\text { countries } \\
\end{array}$ & 849 & 2669 & 3518 & 24 \\
\hline OECD countries & 81 & 3044 & 3125 & 3 \\
\hline World & 930 & 5713 & 6643 & 14 \\
\hline \multicolumn{5}{|c|}{ Region 2020} \\
\hline & Biomass & $\begin{array}{c}\text { Conventional } \\
\text { Energy }\end{array}$ & Total & $\begin{array}{c}\text { Share of } \\
\text { Biomass (\%) }\end{array}$ \\
\hline Africa & 371 & 266 & 637 & 59 \\
\hline China & 224 & 1524 & 1748 & 13 \\
\hline East Asia & 118 & 813 & 931 & 13 \\
\hline Latin America & 81 & 706 & 787 & 10 \\
\hline South Asia & 276 & 523 & 799 & 35 \\
\hline $\begin{array}{c}\text { Total developing } \\
\text { countries }\end{array}$ & 1071 & 3825 & 4896 & 22 \\
\hline $\begin{array}{c}\text { Other non-OECD* } \\
\text { countries }\end{array}$ & 26 & 1669 & 1695 & 2 \\
\hline $\begin{array}{c}\text { Total non-OECD* } \\
\text { countries }\end{array}$ & 1097 & 5494 & 6591 & 17 \\
\hline OECD countries & 96 & 3872 & 3968 & 2 \\
\hline World & 1193 & 9365 & 10558 & 11 \\
\hline
\end{tabular}

*Organisation for Economic Co-operation and Development

Heat tariffs may include a number of components such as a connection charge, a fixed charge and a variable energy charge. Also, consumers may be incentivised to lower the return temperature. Hence, it is difficult to generalise but the heat practice for any DH company no matter what the own- 
ership structure can be highlighted as follows:

- To develop and maintain a development plan for the connection of new consumers.

- To evaluate the options for least cost production of heat.

- To implement the most competitive solutions by signing agreements with other companies or by implementing own investment projects.

- To monitor all internal costs and with the help of benchmarking, and improve the efficiency of the company.

- To maintain a good relationship with the consumer and deliver heat supply services at a sufficient quality.

Installing DH should be pursued to meet the objectives for improving the environment through the improvement of energy efficiency in the heating sector. At the same time DH can serve the consumer with a reasonable quality of heat at the lowest possible cost. The variety of possible solutions combined with the collaboration between individual companies, the district heating association, the suppliers and consultants can, as it has been in Denmark, be the way forward for developing DH in the United Kingdom.

\subsection{Biomass Utilisation and Development of Conversion Technologies}

Sustainable energy is energy that, in its production or consumption, has minimal negative impacts on human health and the healthy functioning of vital ecological systems, including the global environment. The use of sustainably produced biofuels contributes no net atmospheric $\mathrm{CO}_{2}$. Sustainable production assumes that the rate of biofuel utilisation equals the rate of biofuel synthesis, provided that the process does not require a net input of fossil fuels. For example, corn-based ethanol does not fit the description of sustainably produced biofuels in that the corn production requires large amounts of petrochemicals in the form of pesticides and fertilisers. It is an accepted fact that renewable energy is a sustainable form of energy, which has attracted more attention during recent years. A great amount of renewable energy potential, environmental interest, as well as economic consideration of fossil fuel consumption and high emphasis of sustainable development for the future will be needed. Explanations for the use of inefficient agricultural-environmental polices include the high cost of information required to measure benefits on a site-specific basis, information asymmetries between government agencies and farm decision makers that result in high implementation costs, distribution effects and political considerations[70]. As an attractive alternative, agric-environment schemes can be achieved through:

- Sustaining the beauty and diversity of the landscape.

- Improving and extending wildlife habitats.

- Conserving archaeological sites and historic features.

- Improving opportunities for countryside enjoyment.

- Restoring neglected land or features, and

- Creating new habitats and landscapes.

The key to successful future appears to lie with successful marketing of the treatment by products. There is also potential for using solid residue in the construction industry as a filling agent for concrete. Research suggests that the composition of the residue locks metals within the material, thus preventing their escape and any subsequent negative effect on the environment. Measures to maximise the use of high-efficiency generation plants and on-site renewable energy resources are important for raising the overall level of energy efficiency. The world's view of waste has changed dramatically in recent years and it is now seen as a source to feed the ever-growing demand for energy.

\subsection{Efficient Bio-Energy Use and Improvement}

The data required to perform the trade-off analysis simulation can be classified according to the divisions given in Table 9: the overall system or individual plants, and the existing situation or future development. The effective economic utilisations of these resources are shown in Table 10 , but their use is hindered by many problems such as those related to harvesting, collection, and transportation, besides the photo-sanitary control regulations. Biomass energy is experiencing a surge in interest stemming from a combination of factors, e.g., greater recognition of its current role and future potential contribution as a modern fuel, global environmental benefits, its development and entrepreneurial opportunities, etc. Possible routes of biomass energy development are shown in Table 11.

Table 9. Classifications of data requirements

\begin{tabular}{|c|c|c|}
\hline & Plant data & System data \\
\hline Existing data & $\begin{array}{l}\text { Size } \\
\text { Life } \\
\text { Cost (fixed and variation of } \\
\text { Operation and Maintenance) } \\
\text { Forced outage } \\
\text { Maintenance } \\
\text { Efficiency } \\
\text { Fuel } \\
\text { Emissions }\end{array}$ & $\begin{array}{l}\text { Peak load } \\
\text { Load shape } \\
\text { Capital costs } \\
\text { Fuel costs } \\
\text { Depreciation } \\
\text { Rate of return } \\
\text { Taxes }\end{array}$ \\
\hline Future data & $\begin{array}{l}\text { All of above, plus } \\
\text { Capital costs } \\
\text { Construction trajectory } \\
\text { Date in service }\end{array}$ & $\begin{array}{l}\text { System lead growth } \\
\text { Fuel price growth } \\
\text { Fuel import limits } \\
\text { Inflation }\end{array}$ \\
\hline
\end{tabular}

The use of biomass through direct combustion has long been, and still is, the most common mode of biomass utilisation as shown in Tables (9-11). Examples for dry (thermo-chemical) conversion processes are charcoal production from wood (slow pyrolysis), gasification of forest and agricultural residues (fast pyrolysis - this is still in demonstration phase), and of course, direct combustion in stoves, furnaces, etc. Wet processes require substantial amount of water to be mixed with the biomass.

Biomass technologies include:

- Briquetting.

- Improved stoves.

- Biogas.

- Improved charcoal.

- Carbonisation.

- Gasification. 
Table 10. Effective biomass resource utilisation [71]

\begin{tabular}{|c|c|c|}
\hline Subject & Tools & Constraints \\
\hline $\begin{array}{l}\text { Utilisation and land clearance for } \\
\text { agriculture expansion }\end{array}$ & $\begin{array}{l}\text { Stumpage fees } \\
\text { Control } \\
\text { Extension } \\
\text { Conversion } \\
\text { Technology } \\
\end{array}$ & $\begin{array}{l}\text { Policy } \\
\text { Fuel-wood planning } \\
\text { Lack of extension } \\
\text { Institutional }\end{array}$ \\
\hline Utilisation of agricultural residues & $\begin{array}{l}\text { Briquetting } \\
\text { Carbonisation } \\
\text { Carbonisation and briquetting } \\
\text { Fermentation } \\
\text { Gasification }\end{array}$ & $\begin{array}{l}\text { Capital } \\
\text { Pricing } \\
\text { Policy and legislation } \\
\text { Social acceptability }\end{array}$ \\
\hline
\end{tabular}

Table 11. Agricultural residues routes for development

\begin{tabular}{|c|l|l|l|}
\hline Source & Process & Product & End use \\
\hline \multirow{5}{*}{ Agricultural residues } & Direct & Combustion & $\begin{array}{l}\text { Rural poor } \\
\text { Urban household } \\
\text { Industrial use }\end{array}$ \\
\cline { 2 - 4 } & Processing & Briquettes & $\begin{array}{l}\text { Industrial use } \\
\text { Limited household use }\end{array}$ \\
\cline { 2 - 4 } & Processing & $\begin{array}{l}\text { Carbonisation } \\
\text { (Small-scale) }\end{array}$ & Rural household (self sufficiency) \\
\cline { 2 - 4 } & Carbonisation & $\begin{array}{l}\text { Briquettes } \\
\text { Carbonised }\end{array}$ & Urban fuel \\
\cline { 2 - 5 } & Fermentation & Biogas & $\begin{array}{l}\text { Energy services } \\
\text { Household } \\
\text { Industry }\end{array}$ \\
\hline \multirow{4}{*}{$\begin{array}{c}\text { Agricultural and } \\
\text { animal residues }\end{array}$} & Direct & Combustion & (Save or less efficiency as wood) \\
\cline { 2 - 4 } & Briquettes & Direct combustion & (Similar end use devices or improved) \\
\cline { 2 - 4 } & Carbonisation & Carbonised & Use \\
\cline { 2 - 4 } & Carbonisation & Briquettes & Briquettes use \\
\cline { 2 - 4 } & Fermentation & Biogas & Use \\
\hline
\end{tabular}

The increased demand for gas and petroleum, food crops, fish and large sources of vegetative matter mean that the global harvesting of carbon has in turn intensified. It could be said that mankind is mining nearly everything except its waste piles. It is simply a matter of time until the significant carbon stream present in municipal solid waste is fully captured. In the meantime, the waste industry needs to continue on the pathway to increased awareness and better-optimised biowaste recovery. Optimisation of waste carbon may require widespread regulatory drivers (including strict limits on the landfilling of organic materials), public acceptance of the benefits of waste carbon products for soil improvements/crop enhancements and more investment in capital facilities. In short, a significant effort will be required in order to capture a greater portion of the carbon stream and put it to beneficial use. From the standpoint of waste practitioners, further research and pilot programmes are necessary before the available carbon in the waste stream can be extracted in sufficient quality and quantities to create the desired end products. Other details need to be ironed out too, including measurement methods, diversion calculations, sequestration values and determination of acceptance contamination thresholds.

The key to a successful future appears to lie within successful marketing of the treatment by-products. There is also potential for using solid residue in the construction industry as a filling agent for concrete. Research suggests that the composition of the residue locks metals within the material, thus preventing their escape and any subsequent negative effect on the environment

\subsubsection{Briquette}

Charcoal stoves are very familiar to African societies. As for the stove technology, the present charcoal stove can be used, and can be improved upon for better efficiency. This energy term will be of particular interest to both urban and rural households and all the income groups due to the simplicity, convenience, and lower air polluting characteristics. However, the market price of the fuel together with that of its end-use technology may not enhance its early high market penetration especially in the urban low income and rural households.

Briquetting is the formation of a charcoal (an energy-dense solid fuel source) from otherwise wasted agricultural and forestry residues. One of the disadvantages of wood fuel is that it is bulky with a low energy density and is therefore enquire to transport. Briquette formation allows for a more energy-dense fuel to be delivered, thus reducing the transportation cost and making the resource more competitive. It also adds some uniformity, which makes the fuel more compatible with systems that are sensitive to the specific fuel input. 


\subsubsection{Improved Cook Stoves}

Traditional wood stoves can be classified into four types: three stone, metal cylindrical shaped, metal tripod and clay type. Another area in which rural energy availability could be secured where woody fuels have become scarce, are the improvements of traditional cookers and ovens to raise the efficiency of fuel saving. Also, planting fast growing trees to provide a constant fuel supply. The rural development is essential and economically important since it will eventually lead to better standards of living, people's settlement, and self sufficient in the following:

- Food and water supplies.

- Better services in education and health care.

- Good communication modes.

\subsubsection{Biogas}

Biogas technology cannot only provide fuel, but is also important for comprehensive utilisation of biomass forestry, animal husbandry, fishery, agricultural economy, protecting the environment, realising agricultural recycling, as well as improving the sanitary conditions, in rural areas. The wide scale introduction of biogas technology has implications for macro planning such as the allocation of government investment and effects on the balance of payments. Factors that determine the rate of acceptance of biogas plants, such as credit facilities and technical backup services, are likely to have to be planned as part of general macro-policy, as do the allocation of research and development funds[72]. Bacteria form biogas during anaerobic fermentation of organic matters. The degradation is a very complex process and requires certain environmental conditions as well as different bacterial populations. The complete anaerobic fermentation process is briefly described as shown in Table 12, and Figure 3. Biogas is a relatively high-value fuel that is formed during anaerobic degradation of organic matter. The process has been known, and put to work in a number of different applications during the past 30 years, for rural needs such as in[73]: food security, water supply, health cares, education and communications.

Biogas is a generic term for gases generated from the decomposition of organic material. As the material breaks down, methane $\left(\mathrm{CH}_{4}\right)$ is produced as shown in Figure 3. Sources that generate biogas are numerous and varied. These include landfill sites, wastewater treatment plants and anaerobic digesters. Landfills and wastewater treatment plants emit biogas from decaying organic waste.

To date, the waste industry has focused on controlling these emissions to our environment and in some cases, tapping this potential source of fuel to power gas turbines, thus generating electricity. The primary components of landfill gas are methane $\left(\mathrm{CH}_{4}\right)$, and carbon dioxide $\left(\mathrm{CO}_{2}\right)$. The gas stream produced from anaerobic digestion is $\sim 45 \%$ methane, $\sim 55 \% \mathrm{CO}_{2}$. Of course, this depends on the energy content of the input stream.

Other components in the gas are oxygen $\left(\mathrm{O}_{2}\right)$, water vapour and trace amounts of a wide range of non-methane organic compounds (NMOCs). For hot water and heating, renewables contributions come from biomass power and heat, geothermal direct heat, ground source heat pumps, and rooftop solar hot water and space heating systems. Solar assisted cooling makes a very small but growing contribution. When it comes to the installation of large amounts of photovoltaic cells (PVs), the cities have several important factors in common. These factors include:

- A strong local political commitment to the environment and sustainability.

- The presence of municipal departments or offices dedicated to the environment, sustainability or renewable energy.

- Information provision about the possibilities of renewables.

- Obligations that some or all buildings include renewable energy.

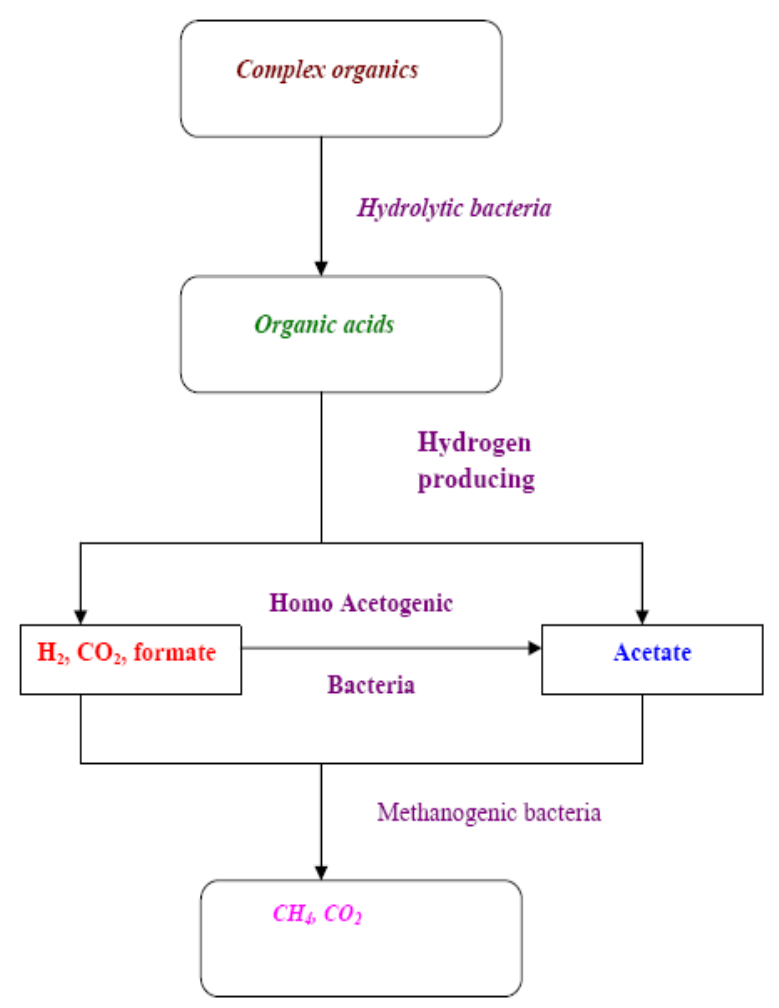

Figure 3. Biogas production process

Table 12. Anaerobic degradation of organic matter[75]

\begin{tabular}{|c|c|c|c|}
\hline Level & Substance & Molecule & Bacteria \\
\hline Initial & Manure, vegetable, wastes & Cellulose, proteins & Cellulolytic, proteolytic \\
\hline Intermediate & Acids, gases, oxidized, inorganic salts & $\mathrm{CH}_{3} \mathrm{COOH}, \mathrm{CHOOH}, \mathrm{SO}_{4}, \mathrm{CO}_{2}, \mathrm{H}_{2}, \mathrm{NO}_{3}$ & Acidogenic, hydrogenic, sulphate reducing \\
\hline Final & Biogas, reduced inorganic compounds & $\mathrm{CH}_{4}, \mathrm{CO}_{2}, \mathrm{H}_{2} \mathrm{~S}, \mathrm{NH}_{3}, \mathrm{NH}_{4}$ & Methane formers \\
\hline
\end{tabular}


During the last decades thousands of biogas units were built all over the world in different areas, producing methane $\mathrm{CH}_{4}$ for cooking, water pumping and electricity generation. D'Apote described in depth the successes stemming from conscientious planning[73-74]. These goals should be achieved through:

- Reviewing and exchanging information on computer models and manuals useful for economic evaluation of biogas production from biomass energy.

- Exchanging and compiling information on methodologies for economic analysis and results from type causes.

- Investigating the constraints on the implementation of the commercial supply of biogas energy.

- Investigating the relations between supplies and demand for the feedstock from different industries.

- Documenting the methods and principles for evaluation of indirect consequences as effects on growth, silvicultural treatment, and employment.

Biogas is a mixture containing predominantly methane (50-65\% by volume) and carbon dioxide, and, in a natural setting, is formed in swamps and anaerobic sediments, etc., due to its high methane concentration, biogas is a valuable fuel. Wet $(40-95 \%)$ organic materials with low lignin and cellulose content are generally suitable for anaerobic digestion. A key concern is that treatment of sludge tends to concentrate heavy metals, poorly biodegradable trace organic compounds and potentially pathogenic organisms (viruses, bacteria and the like) present in wastewaters. These materials can pose a serious threat to the environment. When deposited in soils, heavy metals are passed through the food chain, first entering crops, and then animals that feed on the crops and eventually humans, to whom they appear to be highly toxic. In addition they also leach from soils, getting into groundwater and further spreading contamination in an uncontrolled manner. European and American markets aiming to transform various organic wastes (animal farm wastes, industrial and municipal wastes) into two main by-products:

- A solution of humic substances (a liquid oxidate).

- A solid residue.

In the past two decades the world has become increasingly aware of the depletion of fossil fuel reserves and the indications of climatic changes based on carbon dioxide emissions. Therefore extending the use of renewable resources, efficient energy production and the reduction of energy consumption are the main goals to reach a sustainable energy supply. Renewable energy sources include micro hydroelectic and wind power, solar and geothermal energy, as well as energy from biomass. The technical achievability and the actual usage of these energy sources are different around Europe, but biomass is seen to have a great potential in many of them. An efficient method for the conversion of biomass to energy, is the production of biogas by microbial degradation of organic matter in the absence- of oxygen (anaerobic digestion). It is now possible to produce biogas at rural installations, upgrade it to bio-methane, feed it into the gas grid, use it in a heat demand-controlled CHP and to receive revenues.

Agricultural wastes are abundantly available globally and can be converted to energy and useful chemicals by a number of microorganisms. The biodegradable organic matter was biodegradable to produce biogas and the variation show a normal methanogene bacteria activity and good working biological process as shown in Figures 4-5.

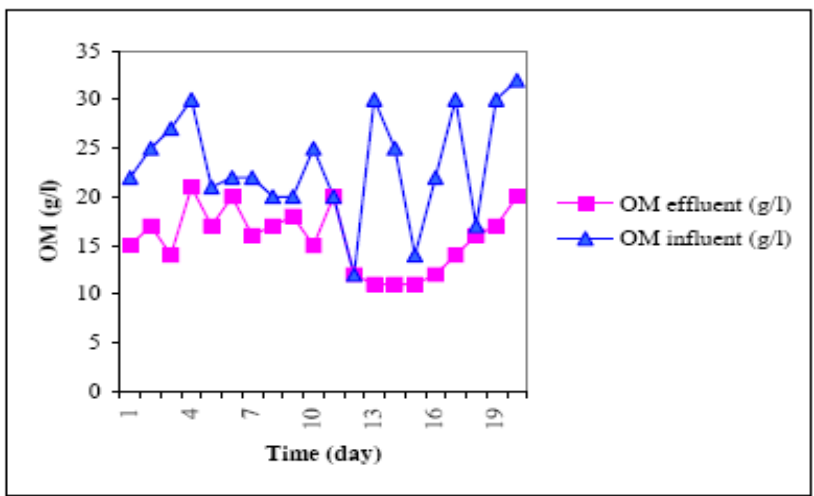

Figure 4. Organic matters before and after treatment in digester [39]

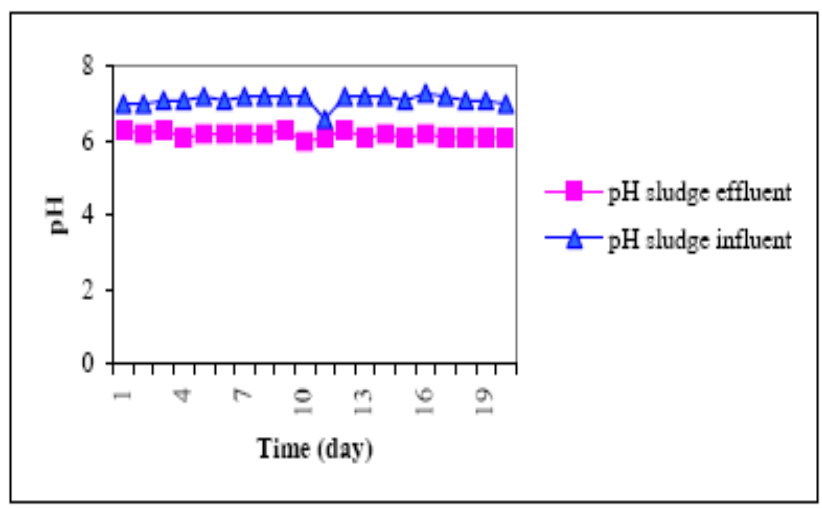

Figure 5. pH sludge before and after treatment in the digester [39]

Within the waste to renewable energy sector, history has shown a hesitancy to invest in projects not supported by four things:

- Adequate independent technology due diligence.

- Security of waste input and power off-take contracts.

- A site with planning permission.

- A reference plant, preferably at scale.

Reviewing the evolution of municipal sewage waste (MSW) management in general, waste collection has tended to progress from incomplete collection through to complete collection and finally to collection with separation into different waste streams. In turn, waste treatment has progressed from ad-hoc decentralised disposal to a strategy more dependent on controlled treatment and disposal, including the use of sanitary landfilling accompanied by waste reduction strategies.

The success of promoting any technology depends on careful planning, management, implementation, training and monitoring. Main features of gasification project are:

- Networking and institutional development/ strengthening.

- Promotion and extension. 
- Construction of demonstration projects.

- Research and development, and training and monitoring.

An easier situation can be found when looking at the ecological effects of different biogas utilisation pathways. The key assumptions for the comparison of different biogas utilisation processes are:

- Biogas utilisation in heat demand controlled gas engine supplied out of the natural gas grid with $500 \mathrm{kWe}$ - electrical efficiency of $37.5 \%$, thermal efficiency of $42.5 \%$, and a methane loss of 0.01 .

- Biogas utilisation in a local gas engine, installed at the biogas plant with $500 \mathrm{kWe}$ - electrical efficiency of $37.5 \%$, thermal efficiency of $42.5 \%$, and a methane loss of 0.5 .

- Biogas production based on maize silage using a biogas plant with covered storage tank - methane losses were $1 \%$ of the biogas produced.

- Biogas upgrading with a power consumption 0.3 $\mathrm{kWhe} / \mathrm{m}^{3}$ biogas - methane losses of 0.5 .

\subsubsection{Improved Forest and Tree Management}

Direct burning of fuel-wood and crop residues constitute the main usage of biomass, as is the case with many developing countries. However, the direct burning of biomass in an inefficient manner causes economic losses and adversely affects human health. In order to address the problem of inefficiency, research centres around the world have investigated the viability of converting the resource to a more useful form, namely solid briquettes and fuel gas (Figure 6). Biomass resources play a significant role in energy supply in all developing countries. Biomass resources should be divided into residues or dedicated resources, the latter including firewood and charcoal can also be produced from forest residues (Table 13).

\subsubsection{Gasification}

Gasification is based on the formation of a fuel gas (mostly $\mathrm{CO}$ and $\mathrm{H}_{2}$ ) by partially oxidising raw solid fuel at high temperatures in the presence of steam or air. The technology can use wood chips, groundnut shells, sugarcane bagasse, and other similar fuels to generate capacities from 3 $\mathrm{kW}$ to $100 \mathrm{~kW}$. Three types of gasifier designs have been developed to make use of the diversity of fuel inputs and to meet the requirements of the product gas output (degree of cleanliness, composition, heating value, etc.). The requirements of gas for various purposes, and a comparison between biogas and various commercial fuels in terms of calorific value, and thermal efficiency are presented in Table 14.

Sewage sludge is rich in nutrients such as nitrogen and phosphorous. It also contains valuable organic matter, useful for remediation of depleted or eroded soils. This is why untreated sludge has been used for many years as a soil fertiliser and for enhancing the organic matter of soil. The road from the initial concept to the production of the first kilowatt of power is long and has many challenges, not least the need for adequate funding. Scientific research evidence, public awareness and increased levels of participation in environmental campaigning have led to governments' worldwide implementing regulations and legislation. Examples include EU landfill diversion directive, recycling targets and climate change regulations. The waste collection, transfer and landfill disposal business comprise a mature, slow-growth industry.

Economic drivers to developing the waste and renewable energy sector have included:

- Waste disposal and landfill gate fees/landfill tax.

- Penalties/avoidance schemes (e.g., landfill allowance schemes and fines; and carbon trading).

- Energy prices.

- Investments subsidies.

Financial institutions across most global markets are gearing themselves up for the environmental revolution. One of the negative results of growing prosperity worldwide has been an increase in waste generation from year to year. When considering the demand and opportunity in today's marketplace these points are prevalent:

Table 13. Biomass residues and current use

\begin{tabular}{|c|c|}
\hline Type of residue & Current use \\
\hline Wood industry waste & Residues available \\
\hline Vegetable crop residues & Animal feed \\
\hline Food processing residue & Energy needs \\
\hline Sorghum, millet, and wheat residues & Fodder, and building materials \\
\hline Groundnut shells & Fodder, brick making, and direct fining oil mills \\
\hline Cotton stalks & Domestic fuel considerable amounts available for short period \\
\hline Sugar, bagasse, and molasses & Fodder, energy need, and ethanol production (surplus available) \\
\hline Manure & Fertiliser, brick making, and plastering \\
\hline
\end{tabular}

Table 14. Comparison of various fuels [75]

\begin{tabular}{|c|c|c|c|}
\hline Fuel & Calorific value (kcal) & Burning mode & Thermal efficiency (\%) \\
\hline Electricity, $\mathrm{kWh}$ & 880 & Hot plate & 70 \\
\hline Coal gas, $\mathrm{kg}$ & 4004 & Standard burner & 60 \\
\hline Biogas, $\mathrm{m}^{3}$ & 5373 & Standard burner & 60 \\
\hline Kerosene, 1 & 9122 & Pressure stove & 28 \\
\hline Charcoal, $\mathrm{kg}$ & 6930 & Open stove & 28 \\
\hline Soft coke, $\mathrm{kg}$ & 6292 & Open stove & 17 \\
\hline Firewood, $\mathrm{kg}$ & 3821 & Open stove & 11 \\
\hline Cow dung, $\mathrm{kg}$ & 2092 & Open stove & \\
\hline
\end{tabular}




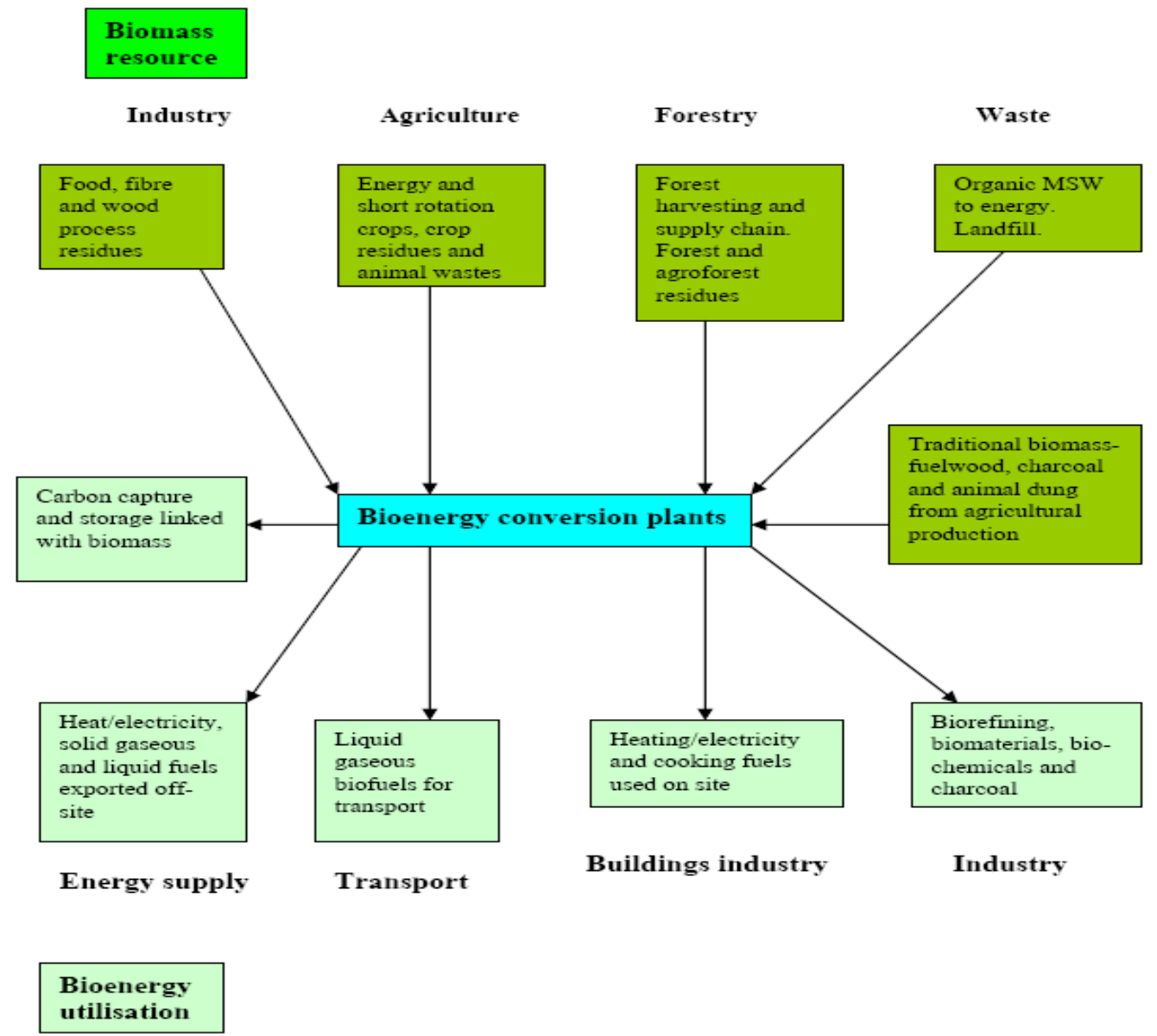

Figure 6. Biomass resources from several sources are converted into a range of products for use by transport, industry and building sectors [73]

The demand for renewable energy is not going to go away.

- The public feeling is that governments across the world are responsible.

- The pressure caused by diminishing fossil fuel supplies is increasing.

- Investment funds are increasingly available from traditional sources.

- The needs for new technologies that can deliver carbon reduction and waste reduction outcomes are increasingly bankable, which opens up the market for all.

A key concern is that treatment of sludge tends to concentrate heavy metals, poorly biodegradable trace organic compounds and potentially pathogenic organisms (viruses, bacteria and the like) present in wastewaters. These materials can pose a serious threat to the environment.

When deposited in soils, heavy metals are passed through the food chain, first entering crops, and then animals that feed on the crops and eventually human beings, to whom they appear to be highly toxic. In addition they also leach from soils, getting into groundwater and further spreading contamination in an uncontrolled manner.

Biomass is a raw material that has been utilised for a wide variety of tasks since the dawn of civilisation. Important as a supply of fuel in the third world, biomass was also the first raw material in the production of textiles. The gasification of the carbon char with steam can make a large difference to the surface area of the carbon. The corresponding stream gasification reactions are endothermic and demonstrate how the steam reacts with the carbon char[74].

$$
\begin{gathered}
\mathrm{H}_{2} \mathrm{O}(\mathrm{g})+\mathrm{Cx}(\mathrm{s}) \rightarrow \mathrm{H} 2(\mathrm{~g})+\mathrm{CO}(\mathrm{g})+\mathrm{C}_{\mathrm{x}-1}(\mathrm{~s}) \\
\mathrm{CO}(\mathrm{g})+\mathrm{H}_{2} \mathrm{O}(\mathrm{g}) \rightarrow \mathrm{CO}_{2}(\mathrm{~g})+\mathrm{H}_{2}(\mathrm{~g}) \\
\mathrm{CO}_{2}(\mathrm{~g})+\mathrm{C}_{\mathrm{x}}(\mathrm{s}) \rightarrow 2 \mathrm{CO}(\mathrm{g})+\mathrm{C}_{\mathrm{x}-1}(\mathrm{~s})
\end{gathered}
$$

\section{Energy and Environmental Problems}

Technological progress has dramatically changed the world in a variety of ways. It has, however, also led to developments of environmental problems, which threaten man and nature. During the past two decades the risk and reality of environmental degradations have become more apparent. The sheer increase in world population, and consumption, industrial activity, throughout the 1970s has guided most environmental analyses and legal control instruments to concentrate on conventional effluent gas pollutants such as $\mathrm{SO}_{2}, \mathrm{NO}_{\mathrm{x}}, \mathrm{CO}_{2}$, particulates, and $\mathrm{CO}$ (Table 15).

Recently, environmental concerns has extended to the control of micro or hazardous air pollutants, which are usually toxic chemical substances and harmful in small doses, as well to that of globally significant pollutants such as $\mathrm{CO}_{2}$. Aside from advances in environmental science, develop- 
ments in industrial processes and structures have led to new environmental problems. For example, in the energy sector, major shifts to the road transport of industrial goods and to individual travel by cars has led to an increase in road traffic and hence a shift in attention paid to the effects and sources of $\mathrm{NO}_{\mathrm{x}}$ and volatile organic compound (VOC) emissions. Environmental problems span a continuously growing range of pollutants, hazards and types of ecosystem degradation. The main areas of environmental problems are: major environmental accidents, water pollution, marine pollution, land use and sitting impact, radiation and radioactivity, solid waste disposal, hazardous air pollutants, ambient air quality, acid rain, stratospheric ozone depletion and global warming (greenhouse effect, and global climate change) (Table 16).

Table 15. EU criteria pollutant standards in the ambient air environment [76]

\begin{tabular}{|c|c|}
\hline Pollutant & EU limit \\
\hline $\mathrm{CO}$ & $30 \mathrm{mg} / \mathrm{m}^{2} ; 1 \mathrm{~h}$ \\
\hline $\mathrm{NO}_{2}$ & $200 \mu \mathrm{g} / \mathrm{m}^{2} ; 1 \mathrm{~h}$ \\
\hline $\mathrm{O}_{3}$ & $235 \mu \mathrm{g} / \mathrm{m}^{2} ; \mathrm{h}$ \\
\hline $\mathrm{SO}_{2}$ & $250-350 \mu \mathrm{g} / \mathrm{m}^{2} ; 24 \mathrm{~h}$ \\
& $80-120 \mu \mathrm{g} / \mathrm{m}^{2} ;$ annual \\
\hline \multirow{2}{*}{$\mathrm{PM}_{10}$} & $250 \mu \mathrm{g} / \mathrm{m}^{2} ; 24 \mathrm{~h}$ \\
\multirow{2}{*}{$\mathrm{SO}_{2}+\mathrm{PM}_{10}$} & $80 \mu \mathrm{g} / \mathrm{m}^{2} ;$ annual \\
\hline $\mathrm{Pb}$ & $100-150 \mu \mathrm{g} / \mathrm{m}^{2} ; 24 \mathrm{~h}$ \\
& $40-60 \mu \mathrm{g} / \mathrm{m}^{2} ;$ annual \\
\hline Total suspended particulate (TSP) & $2 \mu \mathrm{g} / \mathrm{m}^{2} ;$ annual \\
\hline $\mathrm{HC}$ & $260 \mu \mathrm{g} / \mathrm{m}^{2} ; 24 \mathrm{~h}$ \\
\hline
\end{tabular}

Table 16. Significant EU environmental directives in water, air and land environments [77]

\begin{tabular}{|c|l|}
\hline Environment & Directive name \\
\hline \multirow{5}{*}{ Water } & Surface water for drinking \\
& Sampling surface water for drinking \\
& Drinking water quality \\
& Quality of freshwater supporting fish \\
& Shellfish waters \\
& Bathing waters \\
& Dangerous substances in water \\
& Groundwater \\
& Urban wastewater \\
& Nitrates from agricultural sources \\
\hline \multirow{5}{*}{ Air } & Smokes in air \\
& Sulphur dioxide in air \\
& Lead in air \\
& Large combustion plants \\
& Existing municipal incineration plants \\
& New municipal incineration plants \\
& Asbestos in air \\
& Sulphur content of gas oil \\
& Emissions from petrol engines \\
& Air quality standards for NO $\mathrm{N}_{2}$ \\
& Emissions from diesel engines \\
\hline Land & Protection of soil when sludge is applied \\
\hline
\end{tabular}

The four more important types of harm from man's activities are global warming gases, ozone destroying gases, gaseous pollutants and microbiological hazards (Table 17).

The global average temperature is rising, which could lead to the sea level rising at the rate of $60 \mathrm{~mm}$ each decade with the growing risk of flooding in low-lying areas (Figure 7).
During the past century, global surface temperatures have increased at a rate near $0.6^{\circ} \mathrm{C} /$ century and the average temperature of the Atlantic, Pacific and Indian oceans (covering $72 \%$ of the earth surface) have risen by $0.06^{\circ} \mathrm{C}$ since 1995 . Global temperatures in 2001 were $0.52{ }^{\circ} \mathrm{C}$ above the long-term 1880-2000 average (the 1880-2000 annually averaged combined land and ocean temperature is $13.9^{\circ} \mathrm{C}$ ).

At the United Nations Earth Summit at Rio in June 1992 some 153 countries agreed to pursue sustainable development[74]. A main aim was to reduce emission of carbon dioxide and other GHGs.

Reduction of energy use in buildings is a major role in achieving this. Carbon dioxide targets are proposed to encourage designers to look at low energy designs and energy sources. Much evidence exists, which suggests that the future will be negatively impacted if humans keep degrading the environment (Table18).

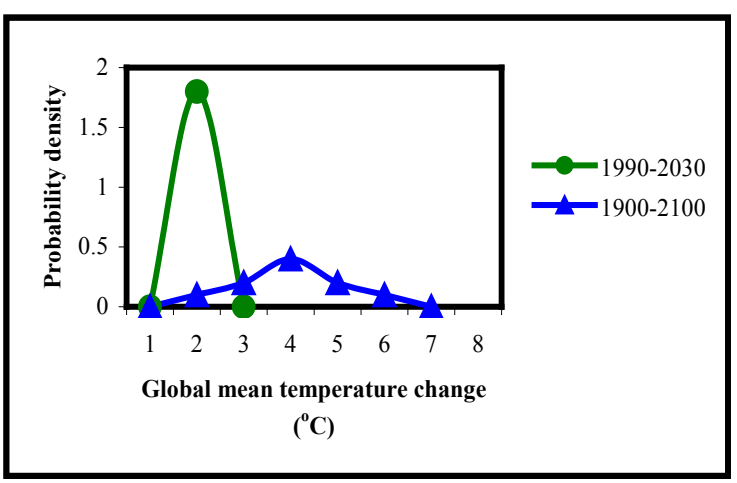

Figure 7. Global mean temperature changes over the period of 1990-2100 and $1990-2030$

Table 17. The external environment [78]

\begin{tabular}{|c|c|c|}
\hline Damage & Manifestation & Design \\
\hline \multirow{2}{*}{$\mathrm{NO}_{\mathrm{x}}, \mathrm{SO}_{\mathrm{x}}$} & Irritant & Acid rain land damage \\
& Acid rain fish damage & $\begin{array}{c}\text { Low } \mathrm{NO}_{\mathrm{x}} \text { burners } \\
\text { Low sulphur fuel } \\
\text { Sulphur removal }\end{array}$ \\
\hline \multirow{2}{*}{$\mathrm{CO}_{2}$} & $\begin{array}{c}\text { Global warming } \\
\text { Rising sea level } \\
\text { Drought, storms }\end{array}$ & $\begin{array}{c}\text { Thermal insulation } \\
\text { Heat recovery } \\
\text { Heat pumps }\end{array}$ \\
\hline \multirow{2}{*}{$\mathrm{O}_{3}$ destruction } & Increased ultra violet & No CFC's or HCFC's \\
& Skin cancer & $\begin{array}{c}\text { Minimum air conditioning } \\
\text { Refrigerant collection }\end{array}$ \\
\hline \multirow{2}{*}{ Legionnellosis } & Crop damage & $\begin{array}{c}\text { Careful maintenance } \\
\text { Dry cooling towers }\end{array}$ \\
\hline
\end{tabular}

Table 18. Global emissions of the top twelve nations by total $\mathrm{CO}_{2}$ volume (billion of tones)

\begin{tabular}{|c|c|c|c|c|c|}
\hline Rank & Nation & $\mathrm{CO}_{2}$ & Rank & Nation & $\mathrm{CO}_{2}$ \\
\hline 1 & USA & 1.36 & 7 & Canada & 0.11 \\
\hline 2 & Russia & 0.98 & 8 & Italy & 0.11 \\
\hline 3 & China & 0.69 & 9 & Mexico & 0.09 \\
\hline 4 & Japan & 0.30 & 10 & Poland & 0.08 \\
\hline 5 & India & 0.19 & 11 & S. Africa & 0.08 \\
\hline 6 & UK & 0.16 & 12 & S. Korea & 0.07 \\
\hline
\end{tabular}

Also, according to the USA Department of Energy, world emissions of carbon are expected to increase by $54 \%$ above 1990 levels by 2015 making the earth likely to warm $1.7-4.9^{\circ} \mathrm{C}$ over the period $1990-2100$, as shown in Figure 8. 


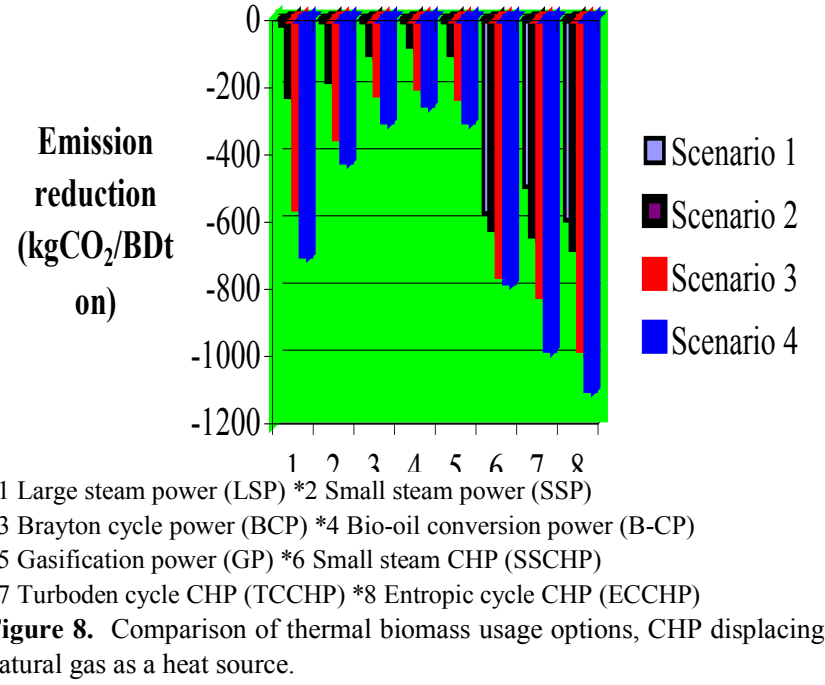

Such observation and others demonstrate that interests will likely increase regarding energy related environment concerns and that energy is one of the main factors that must be considered in discussions of sustainable development.

Lifecycle analysis of several ethanol feedstocks shows the emission displacement per ton of feedstock is highest for corn stover and switchgrass (about 0.65 tons of $\mathrm{CO}_{2}$ per ton of feedstock) and lowest for corn (about 0.5 tons). Emissions due to cultivation and harvesting of corn and wheat are higher than those for lignocellulosics, and although the latter have a far higher process energy requirement (Figure 8). GHG emissions are lower because this energy is produced from biomass residue, which is carbon neutral.

\subsection{Sulphur in Fuels and Its Environmental Consequences}

Coal is formed from plant material deposits according to the peat to anthracite series:

$$
\begin{aligned}
\text { Vegetation } & \rightarrow \text { Peat } \\
& \rightarrow \text { Lignite (brown coal) } \\
& \rightarrow \text { Sub-bituminous coal } \\
& \rightarrow \text { Bituminous coal } \rightarrow \text { Anthracite }
\end{aligned}
$$

Organic sulphur is bound within the organic structure of the coal in the same way that sulphur is bound in simple thioorganics, e.g., thiols. Sulphur contents of coals vary widely, and Table 19 gives some examples.

\subsection{Control of $\mathrm{SO}_{2}$ Emissions}

Emissions will also, of course, occur from petroleum-based or shale-based fuels, and in heavy consumption, such as in steam raising. There will frequently be a need to control $\mathrm{SO}_{2}$ emissions. There are, broadly speaking, three ways of achieving such control:

- Pre-combustion control: involves carrying out a degree of desulfurisation of the fuel.

- Combustion control: incorporating into the combustion system something capable of trapping $\mathrm{SO}_{2}$.

- Post-combustion control: removing $\mathrm{SO}_{2}$ from the flue gases before they are discharged into the atmosphere.
Table 20 gives brief details of an example of each.

Table 19. Representative sulphur contents of coals [79]

\begin{tabular}{|c|c|c|}
\hline Source & Rank & Sulphur content (\%) \\
\hline Ayrshire, Scotland & Bituminous & 0.6 \\
\hline Lancs. /Cheshire, UK & Bituminous & Up to 2.4 \\
\hline S. Wales, UK & Anthracite & Up to 1.5 \\
\hline Victoria, Australia & Lignite & Typically 0.5 \\
\hline Pennsylvania, USA & Anthracite & 0.7 \\
\hline Natal, S. Africa & Bituminous & Up to 4.2 \\
\hline Bulgaria & Lignite & 2.5 \\
\hline
\end{tabular}

Table 20. Examples of $\mathrm{SO}_{2}$ control procedures

\begin{tabular}{|c|c|c|}
\hline Type of control & Fuel & Details \\
\hline Pre-combustion & $\begin{array}{c}\text { Fuels } \\
\text { from } \\
\text { crude oil }\end{array}$ & $\begin{array}{c}\text { Alkali treatment of crude oil to con- } \\
\text { vert thiols RSSR, disulphides; solvent } \\
\text { removal of the disulphides }\end{array}$ \\
\hline Post-combustion & $\begin{array}{c}\text { Coal or } \\
\text { fuel oil }\end{array}$ & $\begin{array}{c}\text { Alkali scrubbing of the flue gases } \\
\text { with } \mathrm{CaCO}_{3} / \mathrm{CaO} \\
\text { Limestone, } \mathrm{MgCO}_{3} \text { and/or other } \\
\text { metallic compounds used to }\end{array}$ \\
\hline Combustion & Coal & Fix the sulphur as sulphates \\
\hline
\end{tabular}

\subsection{The Control of $\mathrm{No}_{\mathrm{x}}$ Release by Combustion Processes}

Emission of nitrogen oxides is a major topic in fuel technology. It has to be considered even in the total absence of fuel nitrogen if the temperature is high enough for thermal $\mathrm{NO}_{\mathrm{x}}$, as it is in very many industrial applications. The burnt gas from the flame is recirculated in two ways:

- Internally, by baffling and restricting flow of the burnt gas away from the burner, resulting in partial flame re-entry.

- Externally, by diverting up to $10 \%$ of the flue gas back into the flame.

\subsection{Wastes}

Waste is defined as an unwanted material that is being discarded. Waste includes items being taken for further use, recycling or reclamation. Waste produced at household, commercial and industrial premises are control waste and come under the waste regulations. Waste Incineration Directive (WID) emissions limit values will favour efficient, inherently cleaner technologies that do not rely heavily on abatement. For existing plant, the requirements are likely to lead to improved control of:

- $\mathrm{NO}_{\mathrm{x}}$ emissions, by the adoption of infurnace combustion control and abatement techniques, and acid gases, by the adoption of abatement techniques and optimisation of their control.

- Particulate control techniques, and their optimisation, e.g., of bag filters and electrostatic precipitators.

The waste and resources action programme has been working hard to reduce demand for virgin aggregates and market uptake of recycled and secondary alternatives. The programme targets are:

- To deliver training and information on the role of recycling and secondary aggregates in sustainable construction for influences in the supply chain, and

- To develop a promotional programme to highlight the new information on websites. 
Table 21. Particle control techniques

\begin{tabular}{|c|l|l|}
\hline Technique & Principle & Application \\
\hline $\begin{array}{c}\text { Gravity } \\
\text { settlement }\end{array}$ & $\begin{array}{l}\text { Natural deposition by gravity of particles from a horizontally flowing } \\
\text { gas, collection in hoppers }\end{array}$ & $\begin{array}{l}\text { Removal of coarse particles ( }>50 \mu \mathrm{m}) \text { from a gas } \\
\text { stream, smaller particles removable in principle but } \\
\text { require excessive flow distances }\end{array}$ \\
\hline $\begin{array}{c}\text { Cyclone } \\
\text { separator }\end{array}$ & $\begin{array}{l}\text { Tangential entry of a particle-laden gas into a cylindrical or conical } \\
\text { enclosure, movement of the particles to the enclosure wall and from } \\
\text { there to a receiver }\end{array}$ & $\begin{array}{l}\text { Numerous applications, wide range of particles sizes } \\
\text { removable, from }=5 \mu \mathrm{m} \text { to }=200 \mu \mathrm{m}, \text { poorer effi- } \\
\text { ciencies of collection for the smaller particles }\end{array}$ \\
\hline Fabric filters & $\begin{array}{l}\text { Retention of solids by a filter, filter materials include woven cloth, felt } \\
\text { and porous membranes }\end{array}$ & Used in dust removal for over a century \\
\hline $\begin{array}{l}\text { Electrostatic } \\
\text { precipitation }\end{array}$ & $\begin{array}{l}\text { Passage of particle-laden gas between electrodes, application of an } \\
\text { electric field to the gas, resulting in acquisition of charge by the } \\
\text { particles and attraction to an electrode where coalescence occurs, } \\
\text { electrical resistivity of the dust an important factor in performance }\end{array}$ & $\begin{array}{l}\text { Particles down to 0.01 } \mu \mathrm{m} \text { removable, extensive } \\
\text { application to the removal of flyash from pulverised } \\
\text { fuel (pf) combustion }\end{array}$ \\
\hline
\end{tabular}

Some of the available control procedures for particles are summarised in Table 21.

\subsection{Sustainable Development}

Several definitions of sustainable development have been put forth, including the following common one: development that meets the needs of the present without compromising the ability of future generations to meet their own needs. A recent World Energy Council (WEC) study found that without any change in our current practice, the world energy demand in 2020 would be 50-80\% higher than 1990 levels.

According to a recent the USA Department of Energy (DoE) report, annual energy demand will increase from a current capacity of 363 million kilowatts to 750 million kilowatts by 2020 . The world's energy consumption today is estimated to 22 billion kWh per year, 53 billion kWh by 2020 . Such ever-increasing demand could place significant strain on the current energy infrastructure and potentially damage world environmental health by $\mathrm{CO}, \mathrm{CO}_{2}, \mathrm{SO}_{2}, \mathrm{NO}_{\mathrm{x}}$ effluent gas emissions and global warming. Achieving solutions to environmental problems that we face today requires long-term potential actions for sustainable development. In this regards, renewable energy resources appear to be one of the most efficient and effective solutions since the intimate relationship between renewable energy and sustainable development. More rational use of energy is an important bridge to help transition from today's fossil fuel dominated world to a world powered by non-polluting fuels and advanced technologies such as photovoltaics (PVs) and fuel cells (FCs).

Growing concerns about social and environmental sustainability have led to increased interests in planning for the energy utility sector because of its large resource requirements and production of emissions. A number of conflicting trends combine to make the energy sector a major concern, even though a clear definition of how to measure progress toward sustainability is yet to emerge. These trends include imminent competition in the electricity industry, global climate change, expected long-term growth in population and pressure to balance living standards (including per capital energy consumption) [80].

Designing and implementing a sustainable energy sector will be a key element for defining and creating a sustainable society. In the electricity industry, the question of strategic planning for sustainability seems to conflict with the shorter time horizons associated with market forces as deregulation replaces vertical integration. Sustainable low-carbon energy scenarios for the new century emphasise the untapped potential of renewable resources. Rural areas can benefit from this transition. The increased availability of reliable and efficient energy services stimulates new development alternatives. It is concluded that renewable environmentally friendly energy must be encouraged, promoted, implemented, and demonstrated by full-scale plant (device) especially for use in remote rural areas.

This is the step in a long journey to encourage a progressive economy, which continues to provide us with high living standards, but at the same time helps reduce pollution, waste mountains, other environmental degradation, and environmental rationale for future policy-making and intervention to improve market mechanisms. This vision will be accomplished by:

- 'Decoupling' economic growth and environmental degradation. The basket of indicators shows the progress being made. Decoupling air and water pollution from growth, making good headway with $\mathrm{CO}_{2}$ emissions from energy, and transport. The environmental impact of our own individual behaviour is more closely linked to consumption expenditure than the economy as a whole.

- Focusing policy on the most important environmental impacts associated with the use of particular resources, rather than on the total level of all resource use.

- Increasing the productivity of material and energy use that are economically efficient by encouraging patterns of supply and demand, which are more efficient in the use of natural resources. The aim is to promote innovation and competitiveness. Investment in areas like energy efficiency, water efficiency and waste minimisation, and encouraging and enabling active and informed individual and corporate consumers.

\section{Conclusions}

The adoption of green or sustainable approaches to the way in which society is run as an important strategy in finding a solution to the energy problem. The key factors to reduce and control $\mathrm{CO}_{2}$ emissions, which are the major contributor to global warming, are the use of alternative ap- 
proaches to energy generation. Even with modest assumptions about the availability of land, comprehensive fuel-wood farming programmes offer significant energy, economic and environmental benefits. These benefits would be dispersed in rural areas where they are greatly needed and can serve as linkages for further rural economic development. The nations as a whole would benefit from savings in foreign exchange, improved energy security, and socio-economic improvements. With a nine-fold increase in forest - plantation cover, a nation's resource base would be greatly improved. The international community would benefit from pollution reduction, climate mitigation, and the increased trading opportunities that arise from new income sources. The non-technical issues, which have recently gained attention, include: (1) Environmental and ecological factors, e.g., carbon sequestration, reforestation and revegetation. (2) Renewables as a $\mathrm{CO}_{2}$ neutral replacement for fossil fuels. (3) Greater recognition of the importance of renewable energy, particularly modern biomass energy carriers, at the policy and planning levels. (4) Greater recognition of the difficulties of gathering good and reliable renewable energy data, and efforts to improve it. (5) Studies on the detrimental health efforts of biomass energy particularly from traditional energy users.

(1). Biogas technology cannot only provide fuel, but is also important for the agricultural economy (through comprehensive utilisation of biomass forestry, animal husbandry, fishery), for protecting the environment, as well as for improving the sanitary conditions; in rural areas.

(2). Biomass energy may gradually replace oil, as demand for the latter increases. Any county can depend on the biomass energy to satisfy an important part of local consumption.

(3). Development of biogas technology is a vital component of alternative rural energy programmes, whose potential is yet to be exploited. Its realisation requires a concerted effort. The technology will find ready-use in domestic, farming, and small-scale industrial applications.

(4). Support biomass research and exchange experiences with countries that are advanced in this field. In the meantime, biomass energy can help delay exhausting worldwide oil reserves.

\section{ACKNOWLEDGEMENTS}

The financial support for this research work from the Energy Research Institute is gratefully acknowledged. It is a pleasure to acknowledge, with gratitude, all those who, at different times and in different ways, have supported the development and evaluation of biomass energy technologies. A special thanks to my spouse Kawthar Abdelhai Ali for her support and her unwavering faith in me. Her intelligence, humour, spontaneity, curiosity and wisdom added to this article.

\section{REFERENCES}

[1] G. Haripriye, "Estimation of biomass in India forests", Biomass and Bioenergy 19 (2000) 245-58

[2] The World Bank, "World development Report 2000/2001", Oxford University Press, UK, (2001)

[3] DEFRA, “Energy Resources Sustainable Development and Environment', Doncaster, UK (2002)

[4] Energy use in offices (EUO), "Energy Consumption Guide 19 (ECG019): Energy efficiency best practice programme', UK Government, London (2000)

[5] G. Anne, S. Michael, "Building and land management", $5^{\text {th }}$ Edition, Oxford: UK (2005)

[6] REN 21, "Renewables global status reports", www.ren21.net (2007)

[7] United Nations, "World Urbanisation Prospect: The 1999 Revision', New York, The United Nations Population Division (2001)

[8] United Nations Economic Commission for Africa (UNECA), "Making Science and Technology Work for the Poor and for SD in Africa", Paper prepared by the SD Division with the assistance of a senior international consultant, Akin Adubifa, January (2011)

[9] United Nations Economic Commission for Africa (UNECA), "The state of food security in Africa', Progress Report of the 3rd Meeting of the Committee on Sustainable Development, 7-10 October, Addis Ababa, Ethiopia (2003)

[10] United Nations Economic Commission for Europe (UNECE) "Note by the ECE Secretariat, Steering Group on Sustainable Development', Second Meeting of the 2003/2004 Bureau', Conference of European Statisticians, Statistical Commission, Geneva, Switzerland (2004)

[11] United Nations Under-Secretary General and the United Nations Environment Programme (UNEP), "Overview: outlook and recommendations", Global Environment Outlook, http://grid.cr.usgs.gov/geo2000/ov-e/0012.htm, Earthscan, 1999, London (2000)

[12] World Bank, "Sustainable Development in the 21st Century", http://nweb18.worldbank.org /ESSD/sdvext.nsf/ 43ByDocName/ Sustainable Development (2011)

[13] World Bank, "World Bank Sustainable Development Reference Guide", http:// www. World Bank Sustainable Development Reference Guide (2011)

[14] World Bank, “World Development Report', Oxford University Press, New York (2003)

[15] World Bank, "Global economic prospects: realizing the development promise of the Doha agenda', The International Bank for Reconstruction and Development, The World Bank, World Bank: Washington, DC (2003)

[16] World Bank, "World Development Report 2004: Making Services Work for Poor People', World Bank: Washington, DC (2004)

[17] A.M. Omer, "Energy demands for heating and cooling equipment systems and technology advancements", In: Natural Resources: Economics, Management and Policy, (2008) 
131-165

[18] A.M. Omer, "Ground-source heat pumps systems and applications", Renewable and Sustainable Energy Reviews, 12 (2008) 344- 371

[19] IEA, "Combined heat and power: evaluating the benefits of greater global investment', (2008)

[20] F. Paul, "Indoor hydroponics", A guide to understanding and maintaining a hydroponic nutrient solution. UK (2001)

[21] G. Huttrer, "The status of world geothermal power generation 1995-2000", Geothermics 30 (2001) 1-27

[22] Reddy, R. Williams, T. Johansson, "Energy after Rio: prospects and challenges. United Nations Development Programme http://www.undp.org/seed/energy/-exec-en.html. (2007)

[23] J.C. Lam, "Shading effects due to nearby buildings and energy implications", Energy Conversion and Management 47(7) (2000) 47-59

[24] Mortal, "Study of solar powered heat pump for small spaces", Portugal, (2002)

[25] S. Shao, et al., "Thermodynamic analysis on heat pumps with economiser for cold regions" China (2002)

[26] L. Roriz, "Determining the potential energy and environmental effects reduction of air conditioning systems", Commission of the European Communities DG TREN (2001)

[27] H. Witte, et al., "Comparison of design and operation of a commercial UK ground source heat pump project", Groenholland BV (2002)

[28] Commission of the European Communities, "Towards a European strategy for the security of energy supply", Green Paper, Brussels, 29 November 2000 COM (2000) 769

[29] T. Trevor, "Fridge recycling: bringing agents in from the cold", Waste Management World, 5 (2007) 43-47

[30] International Energy Agency (IEA), "Indicators for industrial Energy Efficiency and $\mathrm{CO}_{2}$ Emissions: A Technology Perspective',, (2007) 5-16

[31] G. Brain, S. Mark, "Garbage in, energy out: landfill gas opportunities for CHP projects", Cogeneration and On-Site Power, 8 (5) (2007) 37-45

[32] A.M. Omer, "The environmental and economical advantages of agricultural wastes for sustainability development in Sudan", In Proceedings of the $1^{\text {st }}$ Diaspora Conference. Brighton, UK, 24-25 January (2009) 173-182

[33] A.M. Omer, "Biomass energy potential and future prospect in Sudan", Renewable and Sustainable Energy Review, 9 (2005) $1-27$

[34] M. Pernille, "Feature: Danish lessons on district heating", Energy Resource Sustainable Management and Environmental, March/April (2004) 16-17

[35] IPCC, “Climate change (2001) (3 volumes), United Nations International Panel on Climate Change', Cambridge University Press, UK (2001)

[36] R. Lazzarin, A. D'Ascanio, A. Gaspaella, "Utilisation of a green roof in reducing the cooling load of a new industrial building", In: Proceedings of the $1^{\text {st }}$ International Conference on Sustainable Energy Technologies (SET), Porto: Portugal. 12-14 June (2002) 32-37

[37] E. David, "Sustainable energy: choices, problems and opportunities", The Royal Society of Chemistry, 19 (2003) $19-47$

[38] A.M. Omer, "Biomass energy potential and applications", Agriculture Development in Arab World, Vol.19, No.4, Khartoum, Sudan, (2000) 1-15

[39] A.M. Omer, "Agricultural biomass production is an energy option for the future", In: Proceedings of the Dubrovnik Conference on Sustainable Development of Energy, Water and Environment systems, Paper No. 17, ES2 Energy Evaluation, Dubrovnik, Croatia, (2005)

[40] S.O. Aroyeun, et al., "Reduction of aflatoxin B1 and Ochratoxin A in cocoa beans infected with Aspergillus via Ergosterol Value", World Review of Science, Technology and Sustainable Development, Vol. 6, No. 1, (2009) 75-90

[41] Dragana Vilinac. "Plant medicines: an herbalist's perspective", World Review of Science, Technology and Sustainable Development, Vol. 5, No. 2, (2008) 140-151

[42] United Nations, 'Implementation of the United Nations millennium declaration', Report of the Secretary-General, United Nations General Assembly, http://www.un.org (2002)

[43] United Nations (UN), Science and Technology as a Foundation for SD, Summary by the Scientific and Technological Community for the Multi-Stakeholder Dialogue Segment (SD) of the fourth session of the Commission on SD acting as the preparatory committee for the World Summit on SD, Note by the Secretary-General, Commission on SD acting as the preparatory committee for the World Summit on SD Fourth Preparatory Session, 27 May-7 June, (2002)

[44] United Nations (UN), "Global challenge global opportunity: trends in sustainable development', Department of Economics and Social, World Summit on Sustainable Development, Johannesburg, SA (2002)

[45] United Nations Economic Commission for Africa (UNECA), "Address by Josué Dioné: science and technology policies for sustainable development and Africa's global inclusion", Sustainable Development Division ATPS Conference, 11 November, Abuja, Nigeria (2010)

[46] Farm Energy Centre. "Helping agriculture and horticulture through technology, energy efficiency and environmental protection', Warwickshire (2000)

[47] Brain, G., and Mark, S. "Garbage in, energy out: landfill gas opportunities for CHP projects", Cogeneration and On-Site Power, 8 (5) (2007) 37-45

[48] ASHRAE, "Energy efficient design of new building except new low-rise residential buildings", BSRIASHRAE proposed standards 90-2P-1993, alternative GA. American Society of Heating, Refrigerating, and Air Conditioning Engineers Inc., USA. (1993)

[49] V. Crisp, I. Cooper, G. McKennan, "Daylighting as a passive solar energy option: an assessment of its potential in non-domestic buildings", Report BR129-BRE. Garston. UK. 1988

[50] Dieng, R. Wang, "Literature review on solar absorption 
technologies for ice making and air conditioning purposes and recent development in solar technology", Renewable and Sustainable Energy Review (2001); 5 (4): 313-42

[51] UNEP, "Handbook for the International Treaties for the Protection of the Ozone Layer', United Nations Environment Programme. Nairobi: Kenya. (2003)

[52] L. Jeremy, "The energy crisis, global warming and the role of renewables", Renewable Energy World (2005); 8 (2): 1-3.

[53] Zuatori, "An overview on the national strategy for improving the efficiency of energy use", Jordanian Energy Abstracts, 9 (1) (2005) 31-32

[54] A.M. Omer, "Green energies and the environment", Renewable and Sustainable Energy Reviews 12 (2008) 1789-1821

[55] J.W. Lund, D.H. Freeston, T.L. Boyd, "Direct application of geothermal energy: 2005 Worldwide Review", Geothermics 34 (2005) 691-727

[56] A.M. Omer, "Water resources development and management in the Republic of the Sudan", Water and Energy International Journal 61(4) (2004) 27-39. New Delhi, India, October-December

[57] A.M. Omer, "The puzzle of consumption, development and sustainability, In: Proceedings of the National Conference for development and Environment, Khartoum, Sudan", Sudan Engineering Society Journal, Vol.52, No.47, p. 35-43, 18-20 September (2006)

[58] A.M. Omer, "Green energy saving mechanisms", In: Proceedings of the First Plan-Arab Conference on environmental Science and Technology, Part VI Renewable Energy SourcesSolar and Geothermal Energy, Sharjah, UAE, 11-15 March 2007

[59] A.M. Omer, "Green energy saving mechanisms", In: Proceedings of the $6^{\text {th }}$ Jordanian International Mechanical Engineering Conference (JIMEC'6), Amman, Jordan, 22-24 October (2007)

[60] A.M. Omer, "Chapter 6: Energy, water and sustainable development", In: Focus on Sustainable Development Research Advances, Editor: Barton A. Larson, 2007 NOVA Science Publishers, Inc., p.189-205, New York, USA, (2007)

[61] A.M. Omer, "The environmental and economical advantages of agricultural wastes for sustainable development", In: Proceedings of the $16^{\text {th }}$ European Biomass Conference and Exhibition from Research to Industry and Markets, Biomass for Energy, Industry and Climate Protection, Paper No. VP1.2.35 (VP1.2 Biomass Resources), Feria Valencia, Spain, 2-6 June (2008)

[62] A.M. Omer, "Renewable building energy systems and passive human comfort solutions", Renewable and Sustainable Energy Reviews, Vol.12, No.6, p.1562-1587, United Kingdom, August (2008)

[63] A.M. Omer, "People, power and pollution", Renewable and Sustainable Energy Reviews, Vol.12 No.7, p.1864-1889, United Kingdom, September (2008)

[64] A.M. Omer, "Energy, environment and sustainable development", Renewable and Sustainable Energy Reviews, Vol.12, No.9, p.2265-2300, United Kingdom, December (2008)

[65] A.M. Omer, "Focus on low carbon technologies: the positive solution", Renewable and Sustainable Energy Reviews, Vol.12, No.9, p.2331-2357, United Kingdom, December (2008)

[66] A.M. Omer, "Chapter 10: Development of integrated bioenergy for improvement of quality of life of poor people in developing countries", In: Energy in Europe: Economics, Policy and Strategy- IB, Editors: Flip L. Magnusson and Oscar W. Bengtsson, 2008 NOVA Science Publishers, Inc., p.341-373, New York, USA, (2008)

[67] G. Robinson, "Changes in construction waste management", Waste Management World, 3 (2007) 43-492

[68] R.H. Sims, "Not too late: IPCC identifies renewable energy as a key measure to limit climate change", Renewable Energy World, 10 (4) (2007) 31-39

[69] A.M. Omer, "Biogas energy technology in Sudan", Renewable Energy, 28 (3) (2003) 499-507

[70] A.M. Omer, "Review: Organic waste treatment for power production and energy supply", Cells and Animal Biology, 1 (2) (2007) 34-47

[71] A.M. Omer, "Environmental and socio-economic aspect of possible development in renewable energy use", In: Proceedings of the $5^{\text {th }}$ International Congress for South-East Europe on Energy Efficiency and Renewable Energy Sources, Sofia, Bulgaria, 6-8 April (2009)

[72] A.M. Omer, "Renewable energy resources for electricity generation", Renewable and Sustainable Energy Reviews, 11 (7) (2007) 1481-1497, United Kingdom, September (2007)

[73] M. Pernille, "Feature: Danish lessons on district heating", Energy Resource Sustainable Management and Environmental, March/April (2004) 16-17

[74] S.L. D'Apote, "IEA biomass energy analysis and projections", In: Proceedings of Biomass Energy Conference: Data, analysis and Trends, Paris: OECD; 23-24 March (1998)

[75] Bacaoui, A.Yaacoubi, C. Dahbi, J. Bennouna, A. Mazet, "Activated carbon production from Moroccan olive wastes-influence of some factors", Environmental Technology, 19 (1998) 1203-1212

[76] A.M. Omer, "Environmental and socio-economic aspect of possible development in renewable energy use", In: Proceedings of the $4^{\text {th }}$ International Symposium on Environment, Athens, Greece, p.90-100, 21-24 May (2009)

[77] A.M. Omer, "Energy use, environment and sustainable development", In: Proceedings of the $3^{\text {rd }}$ International Conference on Sustainable Energy and Environmental Protection (SEEP 2009), Paper No.1011, Dublin, Republic of Ireland, 12-15 August (2009)

[78] A.M. Omer, "Energy use and environmental: impacts: a general review", Journal of Renewable and Sustainable Energy, Vol.1, No.053101, p.1-29, United State of America, September (2009)

[79] A.M. Omer, "Chapter 3: Energy use, environment and sustainable development", In: Environmental Cost Management, Editors: Randi Taylor Mancuso, 2009 NOVA Science Publishers, Inc., p.129-166, New York, USA (2009)

[80] Omer, A. M. "Green energies and the environment", Renewable and Sustainable Energy Reviews, 12: 1789-1821. 2008 